\title{
Youth Unemployment in 21st Century: The Turkish Case
}

\author{
Asst. Prof. Dr. Kamil Necdet Ar (Okan University, Turkey)
}

\begin{abstract}
The main aim of this paper is to discuss the global youth unemployment problems and review the present situation throughout the World. Youth unemployment is a worldwide severe socio-economic problem today and may develop worse in coming years, unless effective measures are taken. Sorts of inequality which affecting youth unemployment exists throughout the world between rich and poor nations and various social layers of society and all of these waiting solutions. The dimensions of the youth problem is widening in many countries. The proportion of youth unemployment is increasing due to wrong economic and population policies. To tackle all these problems requires new strategies and policies based on fresh visions. In this respect Turkey can be case to review. The dimensions of the youth problem in Turkey is widening like many other developing countries. The proportion of youth unemployment is increasing due to wrong policies. The Turkish is economy cannot support a large growing population under the present circumstances. Also the Turkish education system has to be restructured in order to meet the needs of national and the global labour market demands. In order to solve youth unemployment problems in Turkey, prudential and scientific based policies are to be introduced.
\end{abstract}

\section{Introduction}

For insight into this topic, the global socio economic outlook at the beginning of the 21 century should be reviewed. Extracts from the UN Secretary's 2000 Millennium Report is depicted are provided as follows.

"There are also many things to deplore and to correct. The century just ended was disfigured, time and again, by ruthless conflict. Grinding poverty and striking inequality persist within and among countries even amidst unprecedented wealth. Diseases, old and new, threaten to undo painstaking progress. Nature's life-sustaining services, on which our species depends for its survival, are being seriously disrupted and degraded by our own everyday activities.

The greatest challenge we face today is to ensure that globalization becomes a positive force for all the world's people, instead of leaving billions of them behind in squalor. Inclusive globalization must be built on the great enabling force of then market, but market forces alone will not achieve it. It requires a broader effort to create a shared future, based upon our common humanity in all its diversity. Inclusive globalization must be built on the great enabling force of the market, but market forces alone will not achieve it. It requires a broader effort to create a shared future, based upon our common humanity in all its diversity" (UN, 2000;19-20).

Here we do not see a promising picture. The new capitalist ideology called "globalization" has been in control of the global economy and affairs. However sorts of inequality exists throughout the world between rich and poor nations and various social layers of society. As mentioned in the report, market forces alone will not achieve a fair distribution of wealth and evenly developed societies today and in coming decades unless legitimate social forces intervene. As can be seen in the report the world is witnessing very unfavourable conditions in the 21 st century such as poverty, unemployment, and income inequality. This inequality is growing between the developed and underdeveloped countries, regions and different socio-economic layers in many countries.

In this picture if we focus on youth some international studies such as ILO reports will be useful. According to the recent ILO reports, the world is facing a worsening youth employment crisis: young people are three times more likely to be unemployed than adults and more than 73 million youth worldwide are looking for work. The ILO has warned of young workers facing a dangerous mix of high unemployment, increased inactivity and precarious work in developed countries, as well as persistently high working poverty in the developing world (ILO 2013;7). To continue this subject some useful terminology should be reflected.

\section{Relevant UN Definitions of Unemployment}

In International Labour Organization (ILO) terminology the definition of unemployment is follows;

"The unemployed comprise all persons above a specified age who during the reference period were:

-without work, that is, were not in paid employment or self-employment during the reference period;

-currently available for work, that is, were available for paid employment or self-employment during the reference period; and

- seeking work, that is, had taken specific steps in a specified recent period to seek paid employment or selfemployment" (ILO,1982; para10). If specified for youth the unemployment rate is defined as the number of unemployed youth (typically 15-24 years) divided by the youth labour force (employment+unemployment) (ILO, 2013). 


\section{Globalization and Unemployment}

Globalization has enormous scope to include economic, political, security, environmental, health, social, cultural. Globalization involves not only benefits, but also conflicting interests. This could lead to conflicts of various types at regional, national or international level. One such cost or problem concerns who gains from its potential benefits. There can be substantial inequity in the distribution of the gains from globalization among individuals, impacting individuals, organizations, nations, and regions. Indeed, many of the gains have been going to the rich nations or individuals, creating greater inequalities and leading to potential conflicts nationally and internationally (Ar, 2007; 240-258, Intriligator, 2003;8) For instance the inequality ratio between the richest and poorest countries grew from 1/11 in 1913 to $1 / 44$ in 70s, to 1/ 94.3 in 2005 (UN, 2005; 45).

A second problem stemming from globalization is that of major potential regional or global instabilities stemming from the interdependencies of economies on a worldwide basis. There is the possibility that local economic fluctuations or crises in one nation could have regional or even global impacts (Intriligator;10). An example of this is the "US mortgage crisis" and the "Lehman bankruptcy of 2008" that had global impact. However national policy and technological trends are as important determinants of employment as globalization. The other potential impact of globalization is a diminishing social state and the emergence of complex and interdependent processes over which the state has no control. As proven over time, the recycling economic and financial crisis cannot be prevented by globalization.

After having mentioned all these, in the fifth year after the outbreak of the global financial crisis, global growth has decelerated and unemployment has started to increase again, leaving an accumulated total of some 197 million.

New recession conditions in Europe have been spilling over globally. Lower economic activity and job growth even in countries that had initially escaped these condwave of the crisis constitutes a spillover effect of the weak growth in advanced economies in 2012, in particular in Europe. So far, the main transmission mechanism of global spillovers has been through international trade, but regions such as Latin America and the Caribbean have also suffered from increased volatility of international capital flows that have forced them to quickly adjust their macroeconomic policy in order to dampen the effects on exchange rates, there by weakening their domestic economies.

Above all; the youth unemployment problem is worse than many others. The UN Report emphases the youth employment situation in the following words.

"The world faces a major challenge of youth unemployment - and it is liable to get even worse with the coming youth bulge. According to International Labour Organization estimates, 60 million young people are searching for work but cannot find any; about 80 per cent of them are in developing countries and economies in transition. Those in the 15 to 24 age cohort are nearly twice as likely to be unemployed as adults; in some developing countries the ratio is higher. Young workers are also more likely than older ones to be last hired, first fired; and they are less likely to be protected by legislation. Joblessness among the young can be devastating, and governments have tried, in a number of ways, to deal with it. But policies targeted at young people, including preferential hiring, have proved largely unsuccessful for the simple reason that they are economically unsustainable" (UN, 2000;20-21). Youth make up 17\% of the world's population. There are 1.2 billion youth in the world aged between 15 and $24.87 \%$ of youth live in developing countries. (UN, 2012).

Worldwide 202 million people is unemployed. Among that youth make up $40 \%$ of the world's unemployed .Global Adult Unemployment Rate is 4.5\% (ILO, May 2012). Global Youth Unemployment Rate is 12.6\%. In 2011, youth's risk of being unemployed was 3 times higher than that of an adult (ILO, Youth Trends 2012). A total of 357.7 million youth were not in education, employment, or training (NEET) in 2010, and the number is increasing (World Bank, 2012).

As can be observed job situation for youth is very problematic. What worsens unemployment problem and why are the number of jobs created by economies falling so short of meeting the needs of the jobless, in particular the youth? What impact is the globalization process having on this phenomenon?

The main effects of the process of globalization on the labor market are threefold: it increases the substitutability of capital and labor - as the potential for specialization is increased-; it broadens the technological menu by facilitating international technology transfers and it implies a more or less instantaneous obsolescence of real and human capital employed in non-competitive activities. This implies the automatic unemployment of the human resources associated with that portion of capital stock which suddenly becomes obsolete. Although globalization can improve productivity, investment, and growth, it may not benefit employment and even reduce the earnings of workers" (Beker; 1998).

When these statements are translated, it can be said that with instant information and communication, virtually everything is available to anyone, anywhere. Markets are now global and many corporations are often richer and more powerful than many countries. More in underdeveloped countries but overall the globalization process weakened, destroyed the functions of the social state, public surveillance, and control over corporations. 
International or supranational companies is now in control of global economy and resists any public interference based on social concerns.

\section{World Youth Unemployment in 21. Century}

If we look to the young jobless problem with the perspective outlined above, the global youth unemployment rate, estimated at 12.6 per cent in 2013 , is close to its crisis peak. As many as 73 million young people are estimated to be unemployed in 2013. Meanwhile, informal employment among young people remains pervasive and transitions to decent work are slow and difficult. The economic and social costs of unemployment, long-term unemployment, discouragement and widespread low-quality jobs for young people continue to rise and undermine economies' growth potential (ILO,2013;1) .

As observed in recent international documents youth unemployment is spreading and causing social problems throughout the world. The last ILO document "GLOBAL EMPLOYMENT TRENDS FOR YOUTH 2013" has such a title "A Generation at Risk". Even this title emphases the seriousness of the problem.

Since the unprecedented increase in youth unemployment between 2008 and 2009, the global youth unemployment rate has remained at very high levels. From 2009 to 2011 the youth unemployment rate decreased from 12.7 per cent to 12.3 per cent. It increased again to 12.4 per cent in 2012 and has continued to grow to 12.6 per cent in 2013. This is 1.1 percentage points above the 2007 level of 11.5 per cent. Global youth unemployment is estimated to be 73.4 million in 2013, which is an increase of 3.5 million since 2007 and 0.8 million above the 2011 level (ILO,2013;7).

The global economic crisis caused a massive reduction in jobs, often concentrated in only a small number of sectors. As a result, ever more young unemployed have been forced to consider jobs in sectors or occupations in which they did not work previously, or had not envisaged before entering the labour market. A mismatch may therefore exist between the skills these young people possess and the skills that are demanded by prospective employers. Such a mismatch between skills supply and demand hampers the reallocation of labour and puts upward pressure on unemployment rates (ILO, 2013;21).

The figures in the following shows youth unemployment between the years 2005-2011 in some selected countries. Table 1 displays that youth unemployment is in an unfavourable situation throughout the world. The figures of some selected countries from various geography, development standards and population indicate that even in developed countries youth unemployment is a serious problem.

\begin{tabular}{|l|c|c|c|c|c|}
\hline Country & $\begin{array}{c}\text { Employment } \\
\text { Rate To } \\
\text { Population }\end{array}$ & $\begin{array}{c}\text { Youth } \\
\text { Unemployment } \\
\text { Rate }(\%)\end{array}$ & Country & $\begin{array}{c}\text { Employment } \\
\text { Rate To } \\
\text { Population }\end{array}$ & $\begin{array}{c}\text { Youth } \\
\text { Unemployment } \\
\text { Rate }(\%)\end{array}$ \\
\hline Norway & 65,9 & 9,3 & Argentina & 62,6 & 22,2 \\
\hline Australia & 62,4 & 11,9 & Russian Federation & 62,8 & 15,7 \\
\hline United States & 61,2 & 18,7 & Mexico & 63,9 & 10,4 \\
\hline Netherlands & 61,5 & 7,8 & Kazakhstan & 75 & 5 \\
\hline Germany & 57,2 & 9,1 & Brazil & 68,2 & 23,1 \\
\hline Japan & 59,7 & 8,9 & Turkey & 48,8 & 20,7 \\
\hline Canada & 62,7 & 15,9 & Thailand & 76,9 & 3 \\
\hline France & 54,4 & 23,2 & Pakistan & 55,4 & 10,5 \\
\hline United & 58,8 & 58,8 & World Average & 65,8 & 65,8 \\
\hline
\end{tabular}

Table 1.Youth Unemployment in Selected Countries; Source: Global Employment Trends for Youth 2013, ILO, Geneva, 2013, pp. 174-177.

The jobs crisis pushes more and more women and men out of the labour market. Labour force participation has fallen dramatically, in particular in advanced economies, masking the true extent of the jobs crisis. As a consequence, the employment- to-population ratio has fallen sharply. In this context, youth remain particularly affected and remain particularly stricken by the crisis. In the 2013, some 73.8 million young people are unemployed globally and the slowdown in economic activity is likely to push another half million into unemployment by 2014.

The youth unemployment rate -which had already increased to 12.6 per cent in 2012 - is expected to increase to 12.9 per cent by 2017 . The crisis has dramatically diminished the labour market prospects for young people, as many experience long-term unemployment right from the start of their labour market entry, a situation that was never observed during earlier cyclical downturns (ILO,2013;11). As an example to the decreasing labour force participation and unemployment rates the employment related statistics is laid down in the following. 


\begin{tabular}{|c|c|c|}
\hline Years & $\begin{array}{c}\text { Youth } \\
\text { Unemployment } \\
\text { (Millions) }\end{array}$ & $\begin{array}{c}\text { Youth } \\
\text { Unemployment } \\
\text { Rate (\%) }\end{array}$ \\
\hline 1992 & 65,4 & 10,9 \\
\hline 1994 & 66,5 & 11,4 \\
\hline 1996 & 68,5 & 11,9 \\
\hline 1998 & 70,0 & 12,3 \\
\hline 2000 & 71,2 & 12,7 \\
\hline 2002 & 75,8 & 13,0 \\
\hline 2004 & 76,8 & 12,8 \\
\hline 2006 & 74,9 & 12,3 \\
\hline 2007 & 69,9 & 11,5 \\
\hline 2008 & 70,4 & 11,7 \\
\hline
\end{tabular}

Table 2. Global Youth Unemployment and Unemployment Rates, 1991-2013; Source: Global Employment Trends for Youth 2013, p.8.

Table 2 depicts that under the present global socio-economic conditions which are structured by the global economic powers, the youth unemployment is bouncing up and down .The system in essence has financial and economic crisis recycling within a frequency. As can be seen 10.9 percent youth unemployment in 1992 goes up to 13 percent in 2000 and slides down to 11.5 percent in the coming year and starts to rise again. This picture shows that no realistic remedy to correct the malfunctioning system has been introduced so far and a high rate of youth unemployment has gained a permanent feature. The situation after 2008 is in the following.

\begin{tabular}{|c|c|c|c|c|}
\hline \multicolumn{5}{|c|}{ Labour Force Participation Rate (\%) } \\
\hline Years & 2009 & 2010 & 2011 & $2012 *$ \\
\hline & 60,5 & 60,3 & 60,0 & 60,0 \\
\hline & \multicolumn{5}{|c|}{ Unemployment Rate $(\%)$} \\
\hline Total & $8 ; 4$ & $8 ; 8$ & $8 ; 4$ & $8 ; 6$ \\
\hline Youth & $17 ; 4$ & $18 ; 1$ & $17 ; 6$ & $17 ; 9$ \\
\hline
\end{tabular}

Table 3. Labour Market Situation and Outlook (World); Source: Global Employment Trends2013, ILO Geneva, 2013, p.45. * Projection

Table 3 indicates that after 2008 financial crisis, slight but a steady decline in labour force participation is observed. Youth unemployment rate is high through the period. The problem of an increasing detachment from the labour market is particularly severe among younger people who have been particularly hard hit by the crisis. In the Developed Economies region, youth unemployment rates have risen substantially with the crisis and have not shown signs of improvements since. As recessionary conditions have taken hold of most European countries again, youth unemployment has further increased, reaching more than 50 per cent of young active people in countries such as Greece and Spain and more than 22 per cent in the Euro area overall (ILO,2013,;47). Youth unemployment rate exceeds 15 per cent in two-thirds of advanced economies. Some statistics are in the following.

\begin{tabular}{|l|l|l|l|l|l|}
\hline Country & $2008(\%)$ & $2012(\%)$ & Country & $2008(\%)$ & $2012(\%)$ \\
\hline Switzerland & 8 & 6 & Portugal & 17 & 38 \\
\hline Germany & 12 & 8 & Poland & 18 & 25 \\
\hline Japan & 8 & 8 & Canada & 11 & 15 \\
\hline United States & 12 & 16 & Greece & 20 & 53 \\
\hline United Kingdom & 17 & 20 & Spain & 24 & 51 \\
\hline France & 19 & 22 & Italy & 22 & 32 \\
\hline Sweden & 21 & 22 & OECD Countries & 12 & 16 \\
\hline & & Euro Area (17 Countries) & 15 & 21 \\
\hline
\end{tabular}

Table 4. Youth Unemployment Rates in Selected Countries 2008 and 2012 (Second Quarter, \%); Source: Global Employment Trends for Youth 2013, p. 11

As observed from the table youth unemployment is showing a very sharp increase in some countries such as Spain, Greece, Portugal, Italy. Overall the youth unemployment in the selected countries proves an upward tendency.

So far we have gone through a brief worldwide search on youth unemployment situation. The findings show that the global capitalism has reached to a peak after the fall of socialist bloc and globalization gained huge momentum. International capital has overcome largely over all national supervision and control and gained extreme flexibility between national boundaries and international velocity. However the opponent partner labour 
does not have the same mobility and flexibility as the capital system. Social systems have become obsolete by the pressure of the prevailing extreme capitalist approach .Technological developments which use machines in place of manpower are causing wide scale unemployment and specifically youth unemployment. International corporations dislike social state structures and supervision which have mainly been the support structure for the labour force and the less fortunate. Economic and financial crisis cause adverse impact on unemployment and social security systems in many countries. No doubt, the socio-economic impact on developing (or underdeveloped) countries is much heavier than the developed ones. In this respect Turkey could be an example for brief case research.

\section{Youth Unemployment in Turkey}

Unemployment; youth total (\% of total labor force ages 15-24) in Turkey was last measured at 18.7 in 2013 (22.0 nonagricultural unemployment rate), according to the Turkish Statistical Institute (TurkStat). As mentioned above youth unemployment refers to the share of the labor force ages 15-24 without work but available for and seeking employment. Definitions of labor force and unemployment differ by country. This part has the latest values, historical data, statistics and evaluations for Unemployment - youth total (\% of total labor force ages 1524) in Turkey.

ILO report states that there are 73.8 million young unemployed people in the world. The rate of youth unemployment in Turkey is more than twice the world average. Before looking at beyond 2000, a review of some information covering different periods would be useful. Some vital statistics of the Turkish Statistics Institute (TURKSTAT) pertaining to youth labour and unemployment are in the following.

\begin{tabular}{|c|c|c|c|c|c|c|}
\hline \multirow[b]{2}{*}{ Years } & \multicolumn{3}{|c|}{ Unemployment (\%) } & \multicolumn{3}{|c|}{ Non-agricultural Unemployment (\%) } \\
\hline & Total & Male & Female & Total & Male & Female \\
\hline 1989 & $17 ; 2$ & $17 ; 8$ & $17 ; 2$ & $29 ; 0$ & $25 ; 1$ & $40 ; 3$ \\
\hline 1991 & $17 ; 0$ & $19 ; 2$ & $13 ; 2$ & $30 ; 0$ & $27 ; 8$ & $40 ; 0$ \\
\hline 1993 & $18 ; 2$ & $18 ; 6$ & $15 ; 5$ & $29 ; 9$ & $27 ; 2$ & $37 ; 8$ \\
\hline 1995 & $15 ; 3$ & $15 ; 7$ & $14 ; 6$ & $23 ; 5$ & $20 ; 3$ & $33 ; 3$ \\
\hline 1997 & $15 ; 2$ & $13 ; 9$ & $17 ; 7$ & $23 ; 1$ & $19 ; 1$ & $33 ; 8$ \\
\hline 1999 & $15 ; 2$ & $15 ; 0$ & $15 ; 4$ & $22 ; 6$ & $22 ; 6$ & $30 ; 8$ \\
\hline
\end{tabular}

Table 5. Youth Unemployment Rates of “15-24 age group” by years and sex (1988-1999); Source: Turkish Statistical Institute (Turkstat) household labour force survey.

As observed from the above figures which belong to the last decade before the year 2000, the youth unemployment rates fell both in total and in non-agricultural unemployment figures. This period is the continuation of the centralization period and the Turkstat statistics show a high urbanization ratio in Turkey.

\begin{tabular}{|c|c|c|c|}
\hline Year & Total & Urban Population & $\begin{array}{c}\text { Urban/Rural } \\
\text { Ratio }\end{array}$ \\
\hline 1985 & 50.664 .458 & 26.865 .757 & 53 \\
\hline 2000 & 67.803 .927 & 44.006 .274 & 64.9 \\
\hline
\end{tabular}

Table 6. Population Status (1985-2000; Source: TURKSTAT, Population of Province and district centers.

The table reflects a population boom in cities during the 15 year period. When compared with Table 5, it looks that in the last decade before 2000, job creation by industry and service sector in urban areas could absorb the population growth till to an extent. However this does not take into consideration the growing jobless rate of the youth labour force. When evaluating the total workforce in Turkey and the population increase, in essence it can be said that the number of unemployed youth increased. The youth labour force participation can be viewed in the following.

\begin{tabular}{|c|c|c|c|c|c|c|}
\hline & \multicolumn{3}{|c|}{ Labour Force $(\mathrm{LF}) *$} & \multicolumn{3}{|c|}{ LF Participation Rate (\%) } \\
\hline Years** & Total & Male & Female & Total & Male & Female \\
\hline 1988 & 5.653 & 3.846 & 2.167 & 56.0 & 73.2 & 40.6 \\
\hline 1989 & 5.398 & 3.262 & 2.236 & 55.1 & 70.6 & 41.3 \\
\hline 1991 & 6.200 & 3.898 & 2.302 & 54.4 & 69.9 & 39.6 \\
\hline 1993 & 5.286 & 3.837 & 1.989 & 48.8 & 65.8 & 32.5 \\
\hline 1995 & 6.137 & 3.939 & 1.878 & 49.5 & 65.0 & 34.7 \\
\hline 1997 & 6.137 & 3.950 & 1.653 & 47.1 & 63.8 & 31.1 \\
\hline 1999 & 5.278 & 3.702 & 1.715 & 45.1 & 59.5 & 31.2 \\
\hline
\end{tabular}

Table 7. Labour Force Participation of "15-24 age group” by Years and Sex (1988-1999); Source: TURKSTAT, household labour force survey*1000**Shows the figures of October of each year 
According to the Table 7, the working young population between the beginning and at the end of the 12 year period shows a considerable decline. The total figures reflected above indicate an 11 percent decrease during the 12 year period. Male participation rate drops roughly 14 percent and female participation drops roughly 9 percent. All these facts indicate a diminishing youth labour force participation, although the population of "1524" years of age rose from 10.093 to 12.701 between the years 1988-1999.This picture shows us a large downgrade at youth labour force participation and economy had not been capable of creating sufficient jobs for the growing young population. So to say the problem goes back before the year 2000. Similar statistics going beyond 2000 are also to be looked at.

\begin{tabular}{|c|c|c|c|c|c|c|}
\hline & \multicolumn{3}{|c|}{ Unemployment (\%) } & \multicolumn{3}{|c|}{ Non-agricultural Unemployment (\%) } \\
\hline Years & Total & Male & Female & Total & Male & Female \\
\hline 2000 & 13.1 & 13.7 & 11.9 & 19.0 & 28.0 & 21.7 \\
\hline 2002 & 19.2 & 20.3 & 17.1 & 26.6 & 25.3 & 29.8 \\
\hline 2004 & 20.6 & 20.5 & 20.7 & 26.6 & 24.7 & 31.1 \\
\hline 2006 & 19.1 & 19.3 & 20.6 & 22.5 & 20.2 & 28.1 \\
\hline 2008 & 20.5 & 26.3 & 21.2 & 24.2 & 22.3 & 28.1 \\
\hline 2010 & 21.7 & 21.0 & 23.0 & 22.9 & 21.0 & 26.1 \\
\hline 2012 & 19.8 & 19.0 & 19.9 & 22.9 & 21.0 & 26.1 \\
\hline 2013 & 18.7 & 17.0 & 21.9 & 22.0 & 19.0 & 28.4 \\
\hline
\end{tabular}

Table 8. Youth Unemployment Rates of "15-24 age group" by years and sex, (2000-2004); Source: Turkish Statistical Institute (Turkstat) household labour force survey.

Since the share of agriculture in Turkish economy has declined largely and there is not high unemployment in the agriculture sector in Turkey. The main reason for this, is the widespread family business and labour in the sector. Therefore the real youth unemployment situation can better be monitored by non-agricultural figures. After mentioning that, it should stressed that the youth unemployment figures covering the period 2000-2013 shows a serious increase according to the last decade figures of the Turkish Statistics Institute (TURKSTAT). Youth non-agricultural unemployment rate in Turkey fluctuates around 20- 26 percent level. In other words, one out of four youths is unemployed. The rate of youth unemployment in Turkey is more than the world average. The crisis hit the youth more than it hit the adults. When the reducing labour force participation is added to TURKSTAT unemployment rate figures there should not be any doubt that the real youth unemployment is much higher than 20-25 percent range. By stating that statistics which are to be linked to unemployment rates are in the following.

\begin{tabular}{|c|c|c|c|c|c|c|}
\hline & \multicolumn{3}{|c|}{ Labour Force $(\mathrm{LF}) *$} & \multicolumn{3}{|c|}{ LF Participation Rate (\%) } \\
\hline Years & Total & Male & Female & Total & Male & Female \\
\hline 2000 & 5.401 & 3.317 & 1.821 & 42.5 & 57.6 & 28.1 \\
\hline 2002 & 5.116 & 3.259 & 1.857 & 40.9 & 53.3 & 29.0 \\
\hline 2004 & 4.474 & 2.954 & 1.520 & 37.8 & 51.3 & 25.0 \\
\hline 2006 & 4.365 & 2.908 & 1.458 & 37.4 & 51.1 & 20.6 \\
\hline 2008 & 4.381 & 2.905 & 1.477 & 38.1 & 51.7 & 25.1 \\
\hline 2010 & 4.425 & 2.872 & 1.554 & 38.4 & 50.9 & 26.3 \\
\hline 2012 & 4.442 & 2.910 & 1.512 & 38.2 & 50.8 & 25.9 \\
\hline 2013 & 4.584 & 2.981 & 1.603 & 39.6 & 51.9 & 27.5 \\
\hline
\end{tabular}

Table 9. Labour Force Participation of "15-24 age group” by years and sex (2000-2004); Source: Turkstat, household labour force survey. 1000

Table 9 indicates a serious decline in the number of youth labour force and participation rate. Once all these facts are taken into account it can be said that there is an obvious and serious reduction in youth employment status in 21 st century. The other outstanding issue drifted by these figures the very low young female labour force participation and a double high female unemployment rates compare to male.

It has been customary that female employment in urban agricultural sector has a large scale. However after a fast centralization process, females could not easily participate in industry as workers because of social and cultural pressures which conditioned them in their previous rural life style. For instance to be an industry worker as female in Turkey has usually been disturbing in a man dominated social environment conditioned by old fashioned Middle East mentality.

\section{Contributing Factors to youth unemployment in Turkey}

The highest unemployment is witnessed in the 20-24 age group almost in every country. The lack of experience of new jobseekers, insufficient time to find a job and recent university graduates' high fee expectations can be specified as some factors affecting youth unemployment among others. However there are 
other important factors affecting unemployment. There are various contributing factors to high youth unemployment in Turkey. A major one is high birth ratio. Some related statistics are in the following.

\begin{tabular}{|l|l|l|l|l|}
\hline Years & 2001 & 2005 & 2008 & 2011 \\
\hline Fertility Rate & 2.37 & 2.12 & 2.16 & 2.02 \\
\hline Number of Births & 1.232 .288 & 1.243 .883 & 1.294 .227 & 1.241 .412 \\
\hline Number of Deaths & & & $368.884^{*}$ & 357.367 \\
\hline
\end{tabular}

Table 10. Birth Fertility Rate in Turkey (2001-2011). *2009; Source: Turkstat, Vital Statistics, Basic fertility and mortality indicators.

Although a slight slowdown in fertility rate is seen above, still population increase trend is high in Turkey. Each year roughly 1 million is added to the total specifically to young population. The dynamics of economy is not capable of creating jobs for the present jobless let alone for the new participants. Despite these facts, the present regime is encouraging an increased birth rate through political speeches (Hürriyet Newspaper March 2008). Examples are the "have at least three children campaign", and government consideration of an early retirement benefit for women who have three or more children .It is very likely that having so many children creates a huge burden on poor families and mothers would have no realistic opportunity to join the labour market.

Another factor related to the young unemployment could be the change in the economic structure. The relevant statistics are in the following.

\begin{tabular}{|l|l|l|l|}
\hline Years & Agricultural & Industry & Services \\
\hline 1998 & 12.5 & 32.6 & 51.7 \\
\hline 2006 & 10.0 & 32.9 & 54.5 \\
\hline 2012 & 9.3 & 32.9 & 57.6 \\
\hline
\end{tabular}

Table 11. Gross Domestic Product by Kind of Economic Activity Sector Shares (\%); Source: Turkstat Gross Domestic Product in Constant Prices by Kind of Main Activity (at 1998 Basic Prices).

Table 11 shows that agricultural sector share in annual national revenue has declined for years. Industry share roughly remains unchanged. The share of services has grown considerably. Also TURKSTAT Statistics "Quarterly Production Workers Index of Manufacturing Industry" based on 1997=100 value shows a decline in manufacturing industry which can be perceived the main source of employment and income for labour. The index was 119. 3 in the year 1998, it shows 84.7 in the year 2008.

The facts shown above verify that the labour force released from agriculture and the new labour force participants have been moving to services sector rather than industry because of industrial stagnation. The findings collected from labour force statistics show that unless industrial production growth is realized, unemployment increase cannot be avoided. In this respect the economic policies which have been applied for many years do not serve the aim of an industry production weighted economic structure.

Another survey which was held in 2006 indicates the relationship between education and unemployment. The figures can be viewed below.

\begin{tabular}{|c|c|c|c|c|}
\hline \multicolumn{5}{|l|}{ Labour Force } \\
\hline Age Group & Illiterate & $\begin{array}{r}\text { Less Than } \\
\text { High School }\end{array}$ & High School & $\begin{array}{c}\text { Higher } \\
\text { Education }\end{array}$ \\
\hline $15-19$ & 2.3 & 70.8 & 26.4 & 0.5 \\
\hline $20-24$ & 1.6 & 50.6 & 34.4 & 13.4 \\
\hline $25-29$ & 1.4 & 48.8 & 31.6 & 18.1 \\
\hline $15+$ & 5 & 61 & 21.6 & 12.4 \\
\hline \multicolumn{5}{|l|}{ Employed } \\
\hline $15-19$ & 2.5 & 73.2 & 24.0 & 0.4 \\
\hline $20-24$ & 1.7 & 53.0 & 33.2 & 12.1 \\
\hline $25-29$ & 2.3 & 21.5 & 48.5 & 27.6 \\
\hline $15+$ & 5.3 & 61.4 & 20.9 & 12.4 \\
\hline \multicolumn{5}{|l|}{ Unemployed } \\
\hline $15-19$ & 1.4 & 59.8 & 38.5 & 1 \\
\hline $20-24$ & 1 & 40.9 & 39.5 & 18.5 \\
\hline $25-29$ & 2.8 & 63.4 & 22.2 & 11.6 \\
\hline $15+$ & 2.2 & 57.7 & 28.1 & 12 \\
\hline
\end{tabular}

Table 12. The Educational Status of the Labour Force (\%) 2006; Source: Yentürk Nurhan, Başlevent Cem; Youth Unemployment in Turkey, Istanbul Bilgi University Survey Unit, 2006. 
As seen above high school and higher education graduates of the 20-24 age group face higher unemployment than the adults' high school and college graduates. Being a college graduate does not constitute an advantage and may not be useful for finding jobs in future years.

\section{Conclusions}

Youth employment policy must be designed with the limitations imposed by economic conditions in mind. The problem of youth unemployment cannot be tackled in isolation from the wider macro-economic problems.

The World has been witnessing many recycling financial and economic crisis for many years and especially in recent decades. The new era is called global world and the global ideology is called "globalization". In this system many problems are international, because the economy and money governing powers are global. In this context all socio-economic problems faced in different parts of world are linked to each other in a large scale. Therefore problems such as unemployment in particular youth unemployment is a global problem and the remedies should not be left to a single nation or society. The cooperation, coordination, solidarity between governments, international institutions, organizations are not as vigorous as global capital which seeks low wages to make profit at the expense youth or child abuse throughout the World.

Since the beginning of industrial revolution, the struggle between capital and labour came to a halt after the construction of social state, or welfare state in the second half of $20^{\text {th }}$ century. Nevertheless globalization has gained momentum after the collapse of Soviet Bloc. Globalization in essence is against any state or social interference and the control of world has been moving to the hands of international capitalism. All national social systems and regulations protecting labour against capital and providing a balance between them are being deregulated by inventing several ways. As proved so far the present global system in this nature and structure is a big failure to bring solutions to poverty, inequality, unemployment and to rectify the worldwide social malfunctions. Thus a serious and a strong will of the international community is needed to end several social problems including youth problems.

Youth unemployment is by no means spread evenly across the youth population. Programmes need to be aimed at those young people who are in most need of help in order to counter the dangers of social exclusion of specific groups. Youth unemployment is also particularly associated with drug abuse and crime. Both forms of behaviour which tend to be persistent and which have high social as well as individual costs.

The whole scale introduction of training programmes for young people will do little more than temporarily ease the problem for that group unless measures are taken to ensure that they will be taken on by employers at the end of schemes. Failure to do so may be worse than doing nothing in as much as participation on such schemes may raise the expectations of young participants which are doomed to disappointment if wider ranging policies are not introduced.

To struggle with worldwide and especially with youth problems need new international organizations with fresh and new visions. The influential international organizational structure such as World Bank, IMF and others are all the tools of finance world. Therefore international organizational structure is to be relooked by considering and giving high priority to youth related concerns.

Regarding to Turkey as discussed in this paper youth unemployment is much higher than EU and world average. Male or female youth unemployment in Turkey for many years has been double as adult. To reduce youth unemployment, there is no adequate policies implemented in Turkey. That arise from this environment for young people, young women are more adversely affected. Young people and especially young women-specific policies designed to reduce unemployment would be appropriate.

Firstly Turkey needs to have a youth employment strategy discussed with all parties concerned. When nonagricultural is concerned the adult unemployment rate in 2013 is 12.0 percent and labour force participation is 45.5 percent. The youth non-agricultural unemployment rate in 2013 is 22 percent and youth labour force participation rate is 39.6 percent. These rates of youth unemployment are large enough to require a combination of economic and social policies designed to combat them.

Turkey is in need of some macroeconomic reforms which will contribute to the youth unemployment problem. In this respect population boom is a major problem. The economic growth in 2012 is 2,2 percent . The fertility rate in 2011 is 2.02 percent. In this situation all economic growth is taken by population increase. As brief Turkish economy with a low labour force participation, high unemployment rates and not industry growing economy cannot tolerate a very high population growth. The economic growth in Turkey is not industry production based. Economic growth is not job creating. This problem is also be tackled by the cooperation of all parties rather than government imposed remedies.

Other issue is the education system. In Turkey, as the main cause of educated youth unemployment is the lack of cooperation between education and employment policies. (In the 2013-2014 curriculum year the number of student driven to religious schools is 451.000 . Technical education receiving number of students is 491.000). 
Double female unemployment rate in Turkey is another problem to be addressed. There is need to change the man domination mentality by eliminating social and cultural prejudices.

As conclusion, high rate of population increase, the mismatch between education and employment policies and poor job creating economic growth policies are to be corrected and among all of these reforms high priority should be allocated to the youth unemployment.

We need to go further than simply the aim of employing young people at any cost. We need also to look at the quality of work. Perhaps in times of high youth unemployment, the temptation is to look only at the quantitative effects. There is a need to balance the roles of building or maintaining attachment to the labour market with the desirability of promoting individual choice in the labour market.

\section{References}

- Ar, Kamil Necdet; Wage Trends in Turkey through Globalization Process, Kamu-İş, Ankara, 2007.

- Jones, Barry; The World TurnedUpsideDown? GlobalizationandtheFuture of theState, Manchester UniversityPress, 2000.

- Hürriyet Newspaper, March 2008, Prime Minister's address in Uşak Province.

- Intriligator, Michael D; "Globalization of the World Economy”, MILKEN Institute, LA, Jan. 2003.

- ILO, Resolutions Concerning Economically Active Population, Employment, Unemployment and Underemployment Adopted by the 13th International Conference of Labour Statisticians, October 1982.

- $\quad$ ILO, World of Work Report, Geneva, April, 2012.

- ILO, WorkingwithYouth: AddressingtheYouthEmployment Challenge. May, 2012.

- ILO, Global Employment Trends for Youth, Geneva, May, 2012.

- ILO, Global Employment Trends, Geneva, 2013.

- OECD, "Offto a Good Start? JobsforYouth", 2010

- Turkish Statistical Institute (TURKSTAT) household labour force survey, Labour Force Status of "15-24 Age Group" by years and sex.

- Turkish Statistical Institute (TURKSTAT) Population of Province and district centres.

- TURKSTAT Vital Statistics, Basic fertility and mortality indicators.

- TURKSTAT Gross Domestic Product in Constant Prices by Kind of Main Activity (at 1998 Basic Prices)

- TURKSTAT; Quarterly Production Workers Index of Manufacturing Industry, 2012.

- UN, Millennium Report, 2000.

- UN, Inequality Predicament Report on the World Social Situation, UN, New York, 2005.

- UN, Focal Point for Youth, 2012.

- World Bank. Youth Employment in the Developing World - A profile: Data from World Bank Micro Surveys. mimeo. 2012. Washington D.C:

- Yentürk Nurhan, Başlevent Cem; Youth Unemployment in Turkey, İstanbul Bilgi University Survey Unit, 2006

- Victor Alberto Beker; Globalization and Unemployment: the Case of Argentina , 1998 www.researchgate.net/...Globalization.../9fcfd5...( 03.03.2014) 